Рубан А.В., к.держ.упр., НУЦЗУ, м. Харків, ОRCID: 0000-0002-9174-7315

Ruban A., PhD in Public Administration, Assistant Professor of the Department of supervisory and preventive activities, National University of Civil Defence of Ukraine, Kharkiv

\title{
ВИЗНАЧЕННЯ ПЕРСПЕКТИВНОЇ РЕЗУЛЬТАТИВНОСТІ ДЕРЖАВНО- ГО УПРАВЛІННЯ У СФЕРІ НАЦІОНАЛЬНОЇ БЕЗПЕКИ В УКРАЇНІ
}

\section{DEFINITION OF THE PERSPECTIVE EFFECTIVENESS OF PUBLIC ADMINISTRATION IN THE SPHERE OF NATIONAL SECURITY IN UKRAINE}

У статті детально розглянуто проблематику, перспективність результативності державного управління у сфері начіональної безпеки в Украӥні та інструментарій підтримки начіональної безпеки Украӥни. Визначено ключові завдання моніторингу загроз національній безпечі держави.

Отже, використання спеціальної системи індикаторів й їх гранично припустимих значень с оптимальним підходом за умов необхідності вирішення невідкладних проблем забезпечення національної безпеки, а також стосовно придатності вироблених рекомендацій, орієнтованих на досягнення иілей стратегічного характеру, спрямованих на захист ключових сфер й об'єктів національної безпеки держави.

Ключові слова: державне управління у сфері національної безпеки, перспективна результативність, ризики національної безпеки, індикатори наџіональної безпеки.

The article examines in detail the issues, prospects for the effectiveness of public administration in the field of national security in Ukraine and tools for supporting national security of Ukraine. The key tasks of monitoring threats to the national security of the state have been identified.

Thus, the use of a special system of indicators and their maximum allowable values is the optimal approach in terms of the need to address urgent issues of national security, as well as the appropriateness of the recommendations aimed at achieving strategic goals aimed at protecting key areas and national security.

Keywords: public administration in the sphere of national security, perspective effectiveness, risks of national security, indicators of national security.

Постановка проблеми. Оцінка рівня національної безпеки потребує визначення відповідних індикаторів, а також здійснення кількісної оцінки їх граничних значень. При цьому необхідно відмітити, що в процесі функціонування системи забезпечення національної безпеки ключова роль належить саме гра- 
ничним значенням індикаторів забезпечення національної безпеки. Фактично значення вказаних індикаторів, які не відповідають гранично встановленим, перешкоджають стабільному розвитку держави, та викликають виникнення тенденцій, що спричиняють руйнівні процеси в національній безпеці держави. Виходячи 3 вищевикладеного, моніторинг загроз національній безпеці держави вимагає застосування індикаторів, які відображають майже всі аспекти ії функціонування. При цьому ключовим завданням моніторингу загроз національній безпеці держави є виявлення «біфуркаційних точок» - значень, що можуть критично перевищувати встановлені межі індикаторів, що, в свою чергу, може спричинити наслідки руйнівного характеру для держави в цілому, ії суспільству чи окремим громадянам. Вищезазначене викликає актуальність і необхідність проведення даного дослідження.

Аналіз останніх досліджень і публікацій. Державне регулювання національної безпеки на протязі останніх десятирічь активно привертало увагу дослідників і практиків, зокрема, таких, як: А. Б. Качинський [1], I. С. Руснак [3], Г. П. Ситник [4] та ін.

Однак все ще потребують доопрацювання критерії результативності забезпечення національної безпеки з боку держави.

Мета статті. Метою статті є визначення перспективної результативності державного управління у сфері національної безпеки в Україні.

Для досягнення поставленої мети у роботі ставляться та вирішуються наступні завдання: 1) виокремити індикатори підтримки належного рівня національної безпеки; 2) виділити критерії забезпечення національної безпеки України; 3) встановити критерії для встановлення гранично припустимих значень індикаторів національної безпеки України; 4) сформувати інструментарій підтримки національної безпеки України.

Виклад основного матеріалу. Уся сукупність індикаторів, що дозволяють проаналізувати рівень загроз національним інтересам, повинна бути продіагностована на предмет обрання тих, які дозволяють відобразити критичні «біфуркаційні точки». Саме зазначені показники можуть бути розглянуті в якості граничних значень індикаторів підтримки належного рівня національної безпеки, недотримання яких може спричинити:

- відсутність сталого розвитку держави;

- наявність тенденцій руйнівного характеру в різнохарактерних галузях економіки;

- зниження загального рівня життя населення.

При цьому ключовою перевагою моніторингу забезпечення національної безпеки через використання спеціальної системи індикаторів й їх гранично припустимих значень $€$ те, що він уможливлює відстеження тенденцій процесів, що спостерігаються в усіх іiі сферах, а не на основі аналізу визначених подій. Адже кожна окремо взята подія є наслідком первісного процесу, що спричиняє наявний результат $[1,2]$.

Необхідно враховувати, що встановлення гранично припустимих значень 
гомеостатичної сфери у першу чергу передбачає врахування загроз, що є реальними чи потенційними, а також стратегічних цілей та інструментарію їх досягнення.

Зокрема, їх визначено в наступних нормативних документах держави:

- Конституція України від 28.06.1996 № 254к/96-ВР;

- Стратегія національної безпеки України, затверджена Указом Президента України від 14 вересня 2020 року № 392/2020;

- Закон України «Про основи національної безпеки України» від 21 червня 2018 року № 2469-VIII;

- Закон України та «Про засади внутрішньої і зовнішньої політики» від 1 липня 2010 року № 2411-VI [2, 5].

Вказана методика уможливлює отримання збалансованої системи показників та їх гранично припустимих значень, що, у свою чергу, є дуже вагомим для визначення результативності формування й впровадження державної політики стосовно забезпечення національної безпеки у процесі здійснення моніторингу.

Враховуючи вищезазначене, $\epsilon$ можливість виокремити такі критерії забезпечення національної безпеки України:

- цілі забезпечення національної безпеки;

- реальні та потенційні загрози національній безпеці;

- нормативно-правова база забезпечення національної безпеки $[3,6]$.

Зокрема, під час формування та провадження державної політики забезпечення національної безпеки України, заснованої на індикаторах забезпечення національної безпеки й їх граничних значеннях, мають досліджуватися нагальні проблеми у сфері національної безпеки, i, відповідно, вироблятися супутні рекомендації й особливості їх застосування у межах, визначених державою.

При цьому необхідно здійснювати наступне: 1) застосовувати знання про показники забезпечення національної безпеки й їх гранично припустимі значення для досягнення реальних цілей стратегічного характеру; 2) виявляти причини та джерела загроз національній безпеці; 3) пропонувати плановий комплекс заходів, орієнтований на вирішення проблем національної безпеки.

Вищезазначене свідчить про те, що будь-яка оцінка, заснована на знаннях про показники забезпечення національної безпеки й їх гранично припустимі значення, повинна бути орієнтована на отримання практичного результату, що дозволить досягти поставлених стратегічних цілей забезпечення національної безпеки, а саме засоби, що застосовуються й спрямовуються на захист ключових сфер й об'єктів національної безпеки:

- дотримання конституційних прав і свобод людини і громадянина;

- забезпечення цінностей суспільства духовного, морально-етичного, культурного, історичного, інтелектуального і матеріального характеру;

- захист природних ресурсів та екосистеми, а також інформаційного простору;

- захист державного конституційного устрою, а також територіальної 
цілісності, суверенітету й недоторканості $[5,6]$.

При цьому необхідно зауважити, що вибір засобів й інструментарію підтримки національної безпеки України повинен передбачати наявність: 1) ефективної зовнішньополітичної діяльності; 2) забезпечення безпеки на рівні державного кордону, а також військової безпеки; 3) внутрішньополітичну стабільність; 4) економічну соціальну, екологічну та гуманітарну безпеку; 5) забезпечення стійкого розвитку науково-технологічної сфери; 6) підтримку безпечного стану інформаційної сфери.

Наявні засоби й інструментарій, орієнтовані на забезпечення національної безпеки України, повинні співвідноситися з чітко окресленими національними цінностями, а рішення стратегічного характеру, орієнтовані на забезпечення національної безпеки, повинні грунтуватися на комплексному аналізі зовнішніх і внутрішніх загроз національній безпеці української держави.

Подібний підхід є оптимальним за умов необхідності вирішення невідкладних проблем забезпечення національної безпеки, а також стосовно придатності вироблених рекомендацій, орієнтованих на досягнення цілей стратегічного характеру, спрямованих на захист ключових сфер й об'єктів національної безпеки держави.

Виходячи 3 наведеного вище, в якості критеріїв для встановлення гранично припустимих значень індикаторів національної безпеки України слід обрати наступні: 1) рівень об’єкта, який підлягає захисту з точки зору підтримки національної безпеки; 2) перелік ключових об'єктів забезпечення захисту національної безпеки в державі; 3) ступінь вагомості забезпечення національної безпеки; 4) показники макроекономічного рівня; 5) напрями впливу викликів і загроз (зовнішнього і внутрішнього спрямування); 6) термін впливу загроз (середньота довготривалий); 7) характер ризиків національної безпеки (стратегічного характеру); 8) природа ризиків національної безпеки (кількісні) $[2,5,6]$.

Висновки. У цілому, наступні висновки відображають результати проведеного дослідження.

1. Виокремлено індикатори підтримки належного рівня національної безпеки: відсутність сталого розвитку держави; наявність тенденцій руйнівного характеру в різнохарактерних галузях економіки; зниження загального рівня життя населення.

2. Виділено критерії забезпечення національної безпеки України: цілі забезпечення національної безпеки; реальні та потенційні загрози національній безпеці; нормативно-правова база забезпечення національної безпеки.

3. Встановлено критерії для встановлення гранично припустимих значень індикаторів національної безпеки України: рівень об’єкта, який підлягає захисту з точки зору підтримки національної безпеки; перелік ключових об'єктів забезпечення захисту національної безпеки в державі; ступінь вагомості забезпечення національної безпеки; показники макроекономічного рівня; напрями впливу викликів і загроз (зовнішнього і внутрішнього спрямування); термін впливу загроз (середньо- та довготривалий); характер ризиків національної безпеки (стратегіч166 
ного характеру); природа ризиків національної безпеки (кількісні).

4. Сформовано інструментарій підтримки національної безпеки України: ефективна зовнішньополітична діяльність; забезпечення безпеки на рівні державного кордону, а також військової безпеки; внутрішньополітична стабільність; економічна, соціальна, екологічна та гуманітарна безпека; забезпечення стійкого розвитку науково-технологічної сфери; підтримка безпечного стану інформаційної сфери.

\section{Список використаних джерел:}

1. Качинський А. Б. Індикатори національної безпеки: визначення та застосування їх граничних значень : монографія // А. Б. Качинський. Київ: НІСД, 2013. 101 с.

2. Рубан А. В. Формування дієвих механізмів вирішення проблем державного регулювання у сфері національної безпеки // Публічне управління і адміністрування в Україні. 2019. Вип. 11. С. 141-143.

3. Руснак I. С., Хижняк В. В. Національна безпека та підвищення обороноздатності України в контексті нових викликів і загроз // Стратегічна панорама. 2015. № 1. C. $12-20$.

4. Ситник Г. П. Державне управління у сфері національної безпеки (концептуальні та організаційно-правові засади). Київ: НАДУ, 2011.730 с.

5. Ruban A. The conceptual bases of state regulation of the national security. Authority and Society (History, Theory, Practice), 4(48), 166-167.

6. Ruban A. Research of indicators of state regulation of national security condition of Ukraine. Authority and Society (History, Theory, Practice), 1(49), 135-143.

\section{References:}

1. Kachynskyj, A. B. (2013). Indykatory nacionalnoyi bezpeky: vyznachennya ta zastosuvannya yix granychnyx znachen [Indicators of national security: definition and use of extreme values]. Kyiv : NISD, $101 \mathrm{p}$.

2. Ruban, A. V. (2019). Formuvannya diyevych mexanizmiv vyrishennya problem derzhavnogo regulyuvannya u sferi nacionalnoyi bezpeky [Formation of effective mechanisms of solution of problems of state regulation in the sphere of national security]. Publichne upravlinnya i administruvannya v Ukrayini, 11, 141-143.

3. Rusnak, I. S. (2015). Nacionalna bezpeka ta pidvyshhennya oboronozdatnosti Ukrayiny v konteksti novyx vyklykiv i zagroz [National security and increase in defense capability of Ukraine in the context of new calls and threats], Strategichna panorama, 1, $12-20$.

4. Sytnyk, G. P. (2011). Derzhavne upravlinnya u sferi nacionalnoyi bezpeky (konceptualni ta organizacijno-pravovi zasady) [Public administration in national security sphere (conceptual and institutional framework)], Kyiv : NADU, 2011, 730 p.

5. Ruban, A. (2018). The conceptual bases of state regulation of the national security. Authority and Society (History, Theory, Practice), 4(48), 166-167.

6. Ruban, A. (2019). Research of indicators of state regulation of national security condition of Ukraine. Authority and Society (History, Theory, Practice), 1 (49), 135-143. 